NBER WORKING PAPER SERIES

\title{
GROWING BY LEAPS AND INCHES: \\ CREATIVE DESTRUCTION, REAL COST REDUCTION, AND INCHING UP
}

\author{
Michael R. Darby \\ Lynne G. Zucker \\ Working Paper 8947 \\ http://www.nber.org/papers/w8947 \\ NATIONAL BUREAU OF ECONOMIC RESEARCH \\ 1050 Massachusetts Avenue \\ Cambridge, MA 02138 \\ May 2002
}

An earlier version of this paper was delivered as Michael R. Darby's Presidential Address at the Western Economic Association International Meetings, San Francisco, CA, July 6, 2001. The research has been supported by grants from the University of California's Industry-University Cooperative Research Program, the University of California Systemwide Biotechnology Research and Education Program, and the Alfred P. Sloan Foundation through the NBER Research Program on Industrial Technology and Productivity. We are indebted to many co-authors, postdoctoral fellows, and graduate and undergraduate research assistants who have contributed to the development of these ideas over the last decade. This paper is a part of the NBER's research program in Productivity. The views expressed herein are those of the authors and not necessarily those of the National Bureau of Economic Research.

(C) 2002 by Michael R. Darby and Lynne G. Zucker. All rights reserved. Short sections of text, not to exceed two paragraphs, may be quoted without explicit permission provided that full credit, including (C) notice, is given to the source. 
Growing by Leaps and Inches: Creative Destruction, Real Cost Reduction, and Inching Up Michael R. Darby and Lynne G. Zucker

NBER Working Paper No. 8947

May 2002

JEL No. O30, L11, M13

\begin{abstract}
Most firms achieve perfective progress, incrementally improving commodities or productivity. But technological progress is concentrated in a few firms achieving metamorphic progress: forming or transforming industries with technological breakthroughs (e.g., biotechnology, lasers, semiconductors, nanotechnology). Unless congruent with incumbents' science and technology base, metamorphic progress promotes entry. Scientific breakthroughs embodied in discovering scientists, protected by natural excludability, and transferred by learning-by-doing-with at the bench generally drive metamorphic progress. Embodied knowledge is rivalrous and leads to entry and industry dominance by star-scientist-linked firms. Incorporating this scientific-entrepreneurial process is essential to improving - if not transforming - endogenous growth models.
\end{abstract}

Michael R. Darby

Cordner Professor of Money \& Financial Markets Depts. of Management, Economics \& Policy Studies Anderson Graduate School of Management University of California, Los Angeles

Los Angeles, CA 90095-1481

and NBER

darby@ucla.edu
Lynne G. Zucker

Professor of Sociology \&

Director, Center for International Science, Technology, and Cultural Policy School of Public Policy \& Social Research University of California, Los Angeles Los Angeles, CA 90095-1551 and NBER zucker@ucla.edu 


\section{Growing by Leaps and Inches: Creative Destruction, Real Cost Reduction, and Inching Up}

by Michael R. Darby and Lynne G. Zucker

Drunk: Can you help me find my keys?

Passerby: Sure, where exactly did you drop them?

Drunk: Way over there by the trash can.

Passerby: Then why are you searching over here?

Drunk: The light's much better under the lamppost.

Milton Friedman, Economics 331, Fall 1967

The class laughed on hearing this joke, not yet realizing how well it described the profession for which they were preparing. Even those present who cannot carry memory of a joke home from the barbershop still remember the day they first heard that little joke. The thesis of this paper is that the economics profession has spent years looking for technological progress under the familiar lamppost of research and development (R\&D) by incumbent firms aimed at improvement in existing commodities or productive methods. Such perfective progress (as we term it) is amenable to hedonic measurement and analysis of firm behavior and market equilibrium in terms of return on investment, public goods, and positive externalities. We show here that metamorphic progress associated with creation of new industries or technological transformation of existing industries is of the same or higher order of magnitude as a source of technological progress.

We believe that our approach complements Arnold C. Harberger's recent emphasis on the concentration of growth in a few companies in a few industries which are achieving dramatic real cost reductions. He began to formulate his own schema in his 1990 W.E.A. presidential address and by his 1998 A.E.A. presidential address could report considerable empirical evidence in support of 
this concentration (Harberger 1998). Harberger distinguishes between yeast which makes bread rise evenly and mushrooms which pop up unexpectedly in the back yard. In titling this paper, we had in mind the Japanese picture of progress by inching up - or earlier Frank Knight's (1944) Crusonia plant which grows proportionately except as parts are cut off and eaten. ${ }^{1}$ In contrast, we emphasize the process of this or that industry leaping forward at any given time - a process which may have prompted Schumpeter's (1934) model of creative destruction.

Breakthrough discoveries in science and engineering - particularly invention of a new way of inventing such as corn hybridization, integrated circuits, and recombinant DNA - typically drive metamorphic progress. These discoveries are rarely well understood in the early years following their discovery. As a result, natural excludability is characteristic of these radical technologies due to the extensive tacit knowledge required to practice them and the length period of learning-bydoing-with at the lab bench required to transfer them. Thus, metamorphic progress cannot be analyzed following Arrow's information as a public good paradigm.

The importance of metamorphic progress based on naturally excludable technologies motivates a challenging and exciting research agenda to remove the black box covering the linkages among scientific breakthroughs, high technologies, entry and success in nascent industries, and the movement toward industrial maturity where government statistics and economic research are most likely - coincidentally - to begin. There are real data problems in studying hundreds of private start-up companies in industries still lumped into one or another classification ending in "n.e.c." (not elsewhere classified). They are manageable, however, if economists are willing to exploit unconventional sources and methods more familiar to organizational theorists such as industry directories, financial practitioners' on-line services, the ISI and other scientific literature databases, and sophisticated matching methods for linking firms and individuals across databases. 
Before addressing these central issues, we make a necessary digression in the next section of the paper to clarify the relationship between metamorphic progress and the supposed acceleration of secular productivity growth post-1995 labeled the "New Economy" by Federal Reserve Chairman Alan Greenspan (2000a-b, 2001) and others. ${ }^{2}$ In Section II, we review a large and important sociology of organizations and management literature which has identified recurrent patterns of industry formation. These patterns clearly indicate that the formation process involves decades of change in numbers and average size of firms inconsistent with standard microeconomic analyses of entry and exit for industries in and around equilibrium. We also review equilibrium models of industrial organization, highlighting key points of difference and congruence. In the third section we report in some detail on research on biotechnology by us and others, emphasizing theoretically and empirically interesting results which appear to be generalizable to other industries during their formative and transformative phases. The fourth section focuses on natural excludability which is central to understanding the slow diffusion of very profitable innovations. We then point out the implications of these results for important issues in policy analysis and welfare economics. In the concluding section of the paper we attempt to draft a collective research agenda which suggests some next steps for economics and its sister disciplines in understanding growth and the wealth of nations.

\section{Metamorphic Progress and the "New Economy"}

Experience suggests that our arguments on the importance of metamorphic progress can be misread -- and perhaps dismissed - as supporting or even implying the "New Economy" ideas discussed most significantly by Alan Greenspan (2000a-b, 2001). We have no reason to believe 
that the processes driving metamorphic progress have either accelerated or decelerated in the last half of the 1990s and thus have no expectation of change in either direction of overall technical progress.

Little support for any extraordinary productivity growth in 1996-2000 is found in the 19502001 record of U.S. nonfarm-business labor productivity growth reported in Figure $1 .^{3}$ I believe that the years 1996-2000 are better characterized as years of average productivity growth with one year moderately above average. Despite his best efforts, Rudebusch (2000) was unable to find any statistically significant increase in potential output (corrected for cyclical movements using the demographics-adjusted unemployment rate). ${ }^{4}$ This sort of new economy looks very much like the same old economy. Indeed, 1995-2000 productivity growth was considerably below that experienced in the period 1960-1968 just preceding the Great Inflation. We believe that the evidence is fully consistent with normal procyclical patterns.

In summary, although changes in the rate of metamorphic progress might explain a "New Economy" increase in potential-output growth, we do not believe that has occurred in recent years. Landefeld and Fraumeni (2001) provide a nice review of the debate and measurement issues in regard to the New Economy hypothesis.

\section{Patterns of Industrial Formation}

The typical pattern of formation of new industries involves a few firms initially entering, growing to many, and ultimately consolidating, producing the curve shown in Figure 2 for number of firms. When the number of firms stabilizes or begins to decline, that does not imply however that the overall industry size also declines. What typically happens instead is that the 
remaining, successful entrants grow fast enough that the overall size of the industry continues to increase (as does the average size of the remaining firms), as shown in the industry GDP-share curve in Figure 2. Costs of adjustment in size are generally non-linear, with fixed costs of adjustment rather than the standard assumption of convex adjustment costs, as the review of evidence in Haltiwanger (1997) shows. ${ }^{5}$ Thus, the peak number of firms is reached at a time when industry output is still growing. The general form of the industry life cycle shown in Figure 2 has been strongly supported in empirical research.

We will first review the findings relevant to our main line of argument in the population or organizational ecology approach in the sociology/management literature. We then do the same for the more familiar (to economists) industrial organization literature concerned with learning by firms under competition. We aim to place our own approach in a broader context, not to attempt a global review.

\section{Theories of Population/Industry Emergence and Growth}

Organizational Ecology. Populations of organizations emerge sharing the same "organizational form," meaning "central or core design." Reviews by Baum (1996) and by Singh and Lumsden (1990) identify a wide range of organizational forms, including savings and loan associations, hotels, life insurance companies, day care centers, semiconductor firms, and California wineries. The mixture of private and public organizations is typical of ecological research, and represents exploitation of available data resources rather than systematic comparison across these two sectors.

Most ecological research gathers data on the initial or at least early growth of each organizational form, and sometimes captures the full life cycle of a population as shown in 
Figure 2 above. Organizational ecology focuses attention on the founding/birth of firms and on the population dynamics that support moving from the initial founding of a single firm to emergence of a new industry. Clearly, a population is generally a significantly narrower group of firms than an industry and has the advantage of studying "proto-industries" during the process of their development.

The hypothesized shape of the number of firms curve shown in Figure 2 above has been broadly supported across strikingly different empirical settings, as shown for trade associations by Aldrich and Staber (1988: Figure 7-2 to 7-5), for local units of Mothers Against Drunk Driving (MADD) by McCarthy, Wolfson, Baker, and Mosakowski (1988: Figure 5-1 and 5-2), for labor unions by Carroll and Hannan (1989: Figure 1), for telephone companies by Barnett and Amburgey (1990: Figure 4.1 and 4.3), and for Finnish newspapers by Miner, Amburgey and Stearns (1990: Figures 1, 2, 3). But theory development has not kept pace with empirical work, and the framework within which results can or should be interpreted is often unclear, contradictory, or disconfirmed. Variables proliferate with few validity tests and tenuous relationship to theoretical dimensions of central interest; central theoretical constructs often have no clear empirical referents. ${ }^{6}$

Probably the most robust thread in ecological theory is organizational form, introduced explicitly and developed in McKelvey (1982), McKelvey and Aldrich (1983), and Romanelli (1991). Processes by which new forms are developed include imprinting at the period of emergence in Stinchcombe (1965), and the source and emergence of varieties of forms in Brittain and Freeman (1986), Marrett (1980), and Aldrich and Waldinger (1990).

What underlies the initial emergence and early growth of a new organizational population? Ecological research has only recently gone beyond measuring the effects of the 
number of prior births on the number of births in the next period, called "population dynamics," and the number of organizations in a population in the prior period, called "population density." Zucker, Darby, and Peng (1998) show that fundamentals of resource reallocation and mobilization, coupled with resource quality, provide significantly stronger predictive power especially in predicting location of growth than population dynamics or density. We report repeated dynamic simulations demonstrating that population ecology model predictions are essentially uncorrelated with the panel data on biotechnology entry by year and region, while our alternative model has correlation coefficients averaging above 0.8 .

Industrial Organization. Most theory and research in industrial organization (hereafter, I/O) begins where organizational ecology leaves off. Ecology-based research focuses on the history of development of an organizational population - the process of industry emergence. I/O research has been primarily concerned with firms in mature industries and processes central to mature industry life cycle including growth and turnover, as Caves's recent review (1998) indicates. In mature industries, observed differences in profitability, productivity, industry output shares, investment, and similar variables provide the basis for entry by the firm as well as the basis for later changes in firm strategy, predicting growth and turnover in industries.

Studies in industrial organization broadly support the pattern of change shown in our Figure 2, but only for a subset of companies operating in mature industries, as Caves summarizes (1998:1958-59): "hazard rates for incumbents are lower than for entrants through all stages of the cycle in 'non-technical' products (where experience advantages might be great)," but "higher for 'technical' products, where entrants bring the continuing flow of innovations." The latter results come from Audretsch (1991). Klepper and Miller (1995) and Klepper (1996) show that the number of firms offering a product reaches a long-run stable equilibrium after declining from an 
early peak through a prolonged, steady shake-out phase that suggests continuing competition among firms to reduce costs rather than initial entry that overshot the potential market.

I/O research is based directly on economic theories of competition. From the I/O perspective (Caves 1998, p. 1947, footnote 2), organizational ecology "suffers from eschewing simple priors about business behavior: intended profit-maximization and the need to cover costs to keep a firm's coalition together." Hence, the orienting theories underlying population ecology and I/O are sufficiently different that there has been little cross-fertilization, despite empirical research on the same or very similar underlying processes. ${ }^{7}$

Our research program seeks to build a bridge between these two related approaches by bringing organizational ecology's focus on industry emergence into a model that includes wealth maximization and measures of resources (e.g., intellectual human capital of the stars, venture capital), competencies (e.g., main technology employed), and external environment (beyond other firms to include top quality universities and other local characteristics, as well as quality of the local labor force and national cost of capital).

In standard I/O studies, two major theoretical approaches have developed over the past two decades to deal with empirical inconsistencies with earlier models such as the law of proportionate growth. Central to both are the processes of learning by, and the characteristics of the information available to, firms in an industry: Learning about the decisions and success of other firms, as well as your own firm through its experience, improves the firm's efficiency and hence growth and survival.

Most models of competition and growth are more suited to manufacturing and other routinized production contexts where the main source of uncertainty is arguably how an entering firm will perform relative to existing firms in that same industry. In Jovanovic (1982) and 
Lippman and Rumelt (1982) firms learn about their competitiveness only after entry, through experience relative to that of other firms. Because costs are random, and different between firms, a potential entering firm does not know its own expectation, but knows the distribution of all firms' costs in that industry. Firms differ in size because some discover that they are more efficient than others, not because of fixity of capital. These models have proven themselves in numerous empirical studies of mature industries as reviewed by Caves (1998).

Recent large-scale research in industrial organization has documented the variability of the performance path of individual firms, as shown especially in panel studies by Davis and Haltiwanger (1992) and Pakes and Ericson (1998). A recent model, developed by Ericson and Pakes (1995), explicitly incorporates firm-specific changes in investment in response to chanes in uncertainty and to evolution of competing firms and other industries. The success of the firm in terms of profitability and value is determined by the stochastic outcome of its investment, within the context of success by other firms in the same industry and the context of competitive pressures from new entry and other industries.

This model endogenizes the processes of selection in industry evolution and thus both entry and exit. Industry-level dynamics are predicted to develop over time in an increasingly regular way, spending more time in "natural states," including number of incumbents, entrants and exits, but failing to reach a limit. The Ericson-Pakes approach provides a more complete model of firm behavior in industries where production is not routine, but where central tasks are invented and re-invented as the frontiers of knowledge develop whether due to technological breakthrough or other kinds of invention, from quality circles to new financial instruments. 


\section{Findings for Biotechnology and Other Science-Driven Technological Revolutions}

The process underlying metamorphic progress is defined by the introduction of a new "breakthrough" technology which either eliminates the ability of firms practicing the old technology

to survive or which creates an entirely new industry. ${ }^{8}$ If the technological breakthrough relies on the same scientific and engineering base as the previous technology incumbent firms are generally strengthened as they readily convert to the new technology. Focusing on what happens to incumbent firms, Tushman and Anderson (1986) refer to these changes as "competenceenhancing." If the science and engineering base of the new technology is disjoint from that of the existing technology, existing firms tend to shrink and exit and many new entrants arise practicing the new (incumbent's) "competence destroying" technology (Tushman and Anderson 1986; Henderson 1993).

We emphasize whether the breakthrough technology is incumbent-enhancing or entrygenerating. Incumbent-enhancing breakthroughs are the same as Tushman and Anderson's competence-enhancing breakthroughs. Entry-generating breakthroughs include both their competence-destroying technologies and breakthroughs which create whole new industries. The key example of entry-generating breakthroughs are the entrepreneurial start-up phase in hightechnology industries characterized by a high valuation on ability to practice the new technology while any incumbent firms' expertise in a previous technology becomes obsolete and, often, a barrier to adoption of the new technology.

Much recent research - including ours - has concentrated on industries being formed or transformed in response to entry-generating technological breakthroughs. Nonetheless, Tushman and Anderson (1986) provide an impressive list of incumbent-enhancing breakthroughs and the 
recent work by Harberger (1998) and his associates suggest that metamorphic progress of this type is also a relatively frequent feature of a growing economy. In contrast, we (Darby and Zucker 2001; Zucker and Darby 2001) found in Japan that the technological breakthroughs which led to a wave of entrepreneurial start-ups in the U.S. were adopted more or less successfully either by established firms with congruent scientific bases which took advantage of the opportunity to enter new industries or by technological transformation of incumbent firms. The key institutional difference which appear to have led to different metamorphic processes in the two countries were the (recently relaxed) Japanese prohibition on public offerings of stock in firms without an established record of substantial profitability. The extraordinary length of private financing implied by this prohibition effectively eliminated the possibility of Japanese startup firms financed by venture capitalists.

Research on the formation/transformation entrepreneurial phase in high technology industries has proceeded far enough that we can begin to define and, in some cases, tentatively answer key questions about processes that shape metamorphic change and ultimately the total rate of technological progress in the economy. While we focus here on entry-generating breakthroughs, incumbent-enhancing metamorphic change also may be important for technological progress. ${ }^{9}$

\section{Many Are Called, But Few Are Chosen}

Entry-generating breakthroughs are characterized by a formation phase of perhaps ten to twenty years (see Figure 2) during which many more firms enter the industry than will survive in the long run. In the following consolidation or shakeout phase of perhaps ten to thirty years, most of these firms are either absorbed by the industry's winners or leave the industry at their

owners' initiative or that of their creditors. ${ }^{10}$ This occurs even as industry output continues to 
grow dramatically; average (surviving) firm size grows even more rapidly. The consolidation phase may be followed by an extended period of stability corresponding to the standard pricetheory model of entry and exit maintaining zero-economic profits and optimal firm size. A final phase of decline is not necessary but often observed. Alternatively, the entire process may be interrupted in any phase by another metamorphic breakthrough.

Why are so many more new firms or new operations of existing firms created than are really needed? Is their creation and destruction a case of organizational waste and entrepreneurial misjudgment or is firm-number overshooting valuable and entry ex ante justified? Uncertainty about which entrants will be most successful in implementing the new technology is sufficient for the observed pattern to be efficient, as shown by Jovanovic and MacDonald (1994) and Ericson and Pakes (1995), and recently elaborated by Bernardo and Chowdhry (2002).

For incumbent-enhancing breakthroughs it is obvious that the most successful implementers will be among the incumbent firms where so much expertise relative to the technology and cooperative technologies is present. Indeed, one or more of these firms is likely to be the source of the breakthrough. While inventing and early adopting incumbent firms are likely to improve their standing in the industry (Tushman and Anderson 1986), there is no reason for any outsiders to enter in the expectation that they will out-compete the incumbents. Thus the overshooting of firm numbers is characteristic of only entry-generating metamorphic progress.

Although there are many hopeful entrants in the latter case, few of them typically survive. For example, Table 1 presents some data on U.S. new biotechnology firms in 1989 drawn from a study we did with Jeff Armstrong. ${ }^{11}$ The first of these firms was founded in 1976 to exploit the string of technological breakthroughs in the life sciences, most of which followed directly or indirectly from the invention of genetic engineering as reported by Cohen, Chang, Boyer, and 
Helling (1973). Firm formation accelerated after the 1980 U.S. Supreme Court decision which upheld the patenting of engineered cells and cell parts and the underlying recombinant-DNA technology covered by the Cohen-Boyer patent (1980). By 1990 over half of the employees in the industry were concentrated in the top 10 percent of the firms and over two thirds of the industry were in the top 20 percent of the firms. Figure 3 illustrates these data and shows that the same top-21 firms (out of 211) also accounted for 54 percent of the growth in employment from 1989 to $1994 .{ }^{12}$ More generally, Lamoreaux and Sokoloff (2002, Table 6) show that U.S. patents have been concentrated in a relatively few career inventors since the 1870s.

\section{Academic Science Matters a Lot}

Entry-generating metamorphic progress almost always arises from outside the industry(ies) to which it will be applied. Many observers have pointed to anecdotal evidence of the importance of research universities as a source of breakthroughs which have created such regions as the Silicon Valley around Stanford, Route 128 around M.I.T. and Harvard, and the Research Triangle around Duke, the University of North Carolina-Chapel Hill, and North

Carolina State University. ${ }^{13}$ Mansfield (1995) documents the important role played by academic research in even incremental industrial R\&D, i.e., in perfective progress.

A stream of recent research on innovation in the U.S. has found evidence of "geographically localized knowledge spillovers" occurring in areas around major universities: Jaffe $(1986,1989)$, Jaffe, Trajtenberg, and Henderson (1993), Audretsch and Feldman (1996), and Henderson, Jaffe, and Trajtenberg (1998). The underlying assumption is that proximity to a major university itself provides technological opportunity; the localization is assumed to be due to the social ties between university and firm employees or to firm employees' access to seminars at the university. The 
importance of distance is strengthened by Adams and Jaffe's (1996) finding that geographic distance is an important impediment to flow of technology even within the firm.

Zucker, Darby, and Brewer (1998) and Darby and Zucker (2001) find that firms are more likely to begin using biotechnology near where and when "star" bioscientists are actively publishing in the U.S. and Japan, respectively. Although these findings have been cited as evidence of geographically localized knowledge spillovers, we read our results - and those of the other authors cited above - as only demonstrating geographical localization of knowledge. Zucker, Darby, and Armstrong $(1998,2002)$ and Zucker and Darby (2001) show for California, the U.S., and Japan, respectively, that university effects on nearby firm R\&D productivity are highly concentrated in the particular firms with bench-science working relationships with top academic scientists and practically absent otherwise. We identify these academic-firm links by the academic scientist publishing a journal article that also has one or more firm-affiliated authors. ${ }^{14}$ Table 2 and the corresponding Figure 4 indicate the close connection between links to top research university faculty and success: ranking firms by their linked articles up to 1989 does about as well as ranking by 1989 employment at predicting the 1989-1994 employment increase. Put another way, an investor who restricted his or her biotech portfolio at the end of 1989 to only the 22.7 percent of firms with any linked firm-research university core biotech publications or the 10.9 percent with more than one or two of these would include all of the top-10 firms and nearly all of the base-hit firms. The message of these simple correlations holds up in the context of poison regressions which allow for other determinants. Figure 5 reports the strong estimated effects of these linked articles on firm research productivity in California and Japan. ${ }^{15}$

Fieldwork - supported by analysis of the timing of the academic scientists' first articles with a firm and its founding -- indicates that these academic-firm co-publishing relationships most often 
connote that the academic scientist was a firm founder or at least presently has a significant financial interest in the firm. ${ }^{16}$ Indeed, Herbert Boyer of the Cohen-Boyer team which discovered recombinant-RNA or genetic engineering and entrepreneur Robert Swanson founded the first of the new biotech firms (Genentech). Similarly, Torero (1998) finds that a few hundred top scientists and engineers account for a large part of the patenting in the semiconductor industry, and firm success depends heavily on the degree of involvement of those stars in a firm. Where and when these star semiconductor scientists and engineers are working is an important determinant of where and when new semiconductor firms are established (Torero, Darby, and Zucker 2001).

\section{Natural Excludability and the Diffusion of Metamorphic Breakthroughs}

The central role of a relatively small number of scientists and engineers in determining success of high-technology firms forces us to rethink the nature of technology. Economists have traditionally analyzed technology as if it were a public good with a marginal cost of (re)production of zero (Nelson 1959, Arrow 1962). Despite the seminal works of Stigler (1961) and Becker (1964) spawning the vast literatures on the economics of costly information and human capital, most analyses of technology including the "new" endogenous growth models typically conceive of technology as information that can be recorded on a floppy diskette and then be costlessly reproduced and applied. Romer (1990, p. S75), for example, acknowledges that this nonrivalrous characterization is an idealization but argue that it is much more expensive to create a new technology than learn it and that the idealization is harmless. We disagree.

When a major scientific breakthrough occurs and creates the opportunity for a corresponding incumbent-enhancing or entry-generating technological breakthrough, it may be 
very difficult for anyone other than the discovering scientists or their close working associates to reduce the discovery to technological practice. The ideas are far from codified and even the discovering scientists are not sure exactly what it is that they are doing which is crucial. Published results - including those in a patent - may not be reproducible unless the reproducing scientist goes to the discoverer's lab and learns by doing with him or her. ${ }^{17}$ In biotechnology, patent disclosures are often made by deposit of a cell line with an independent agent so that they will be publicly available at the expiration of the patent term: it is simply not possible to write down what a person "skilled in the art" would have to do to obtain the same organism.

Breakthrough discoveries leading to metamorphic growth are often of the same nature as Griliches's classic case of $(1957,1960)$ corn hybridization: an invention of a way of invention. Such platform technologies involving new techniques and instrumentation are typically hard to work with at first and their diffusion is based on learning-by-doing-with at the laboratory bench: that is, by immediate observation and practice with someone who holds the tacit knowledge of how to make the technique work.

Not only are breakthrough discoveries often characterized by extensive tacit knowledge, only a relatively few top scientists near the frontier of the area are likely to be able to figure out how the discovery might be used to actually produce something of economic value. While everyone might want to pluck the newly available low-lying fruit, not everyone can see where they are. The late Robert Swanson, the founding CEO of Genentech, liked to tell the story of how the firm obtained such a favorable royalty deal for Humulin ${ }^{\circledR}$ (human insulin produced by genetically modified bacteria) from the usually shrewd bargainers at Eli Lilly and Co.: The scientists there were so sure that Herbert Boyer and Genentech were attempting the impossible that no serious 
bargaining was done until Genentech notified Lilly that they were holding a press conference announcing success in three days.

We say that this embodied knowledge - transferred slowly only be learning-by-doing-with is characterized by natural excludability. Even if the university is assigned a patent to the discovery most of the value accrues to the discoverers since without their cooperation the patent cannot be used. Our fieldwork for biotechnology and more general studies by Jensen and Thursby (2001) and Thursby and Thursby (2002) support the natural excludability hypothesis. For example, in the Jensen and Thursby (2001, p. 243) survey of Technology Transfer Office managers, "For 71 percent of the inventions licensed, respondents claim that successful commercialization requires cooperation by the inventor and licensee in further development."

\section{Diffusion with Natural Excludability}

If new metamorphic technologies were really like software on a disk, diffusion of this highly profitable knowledge would be limited only by the speed with which people realize the value of the new processes (Mansfield 1961, Griliches and Schmookler 1963). In contrast to this potentially infinite rate of adoption, natural excludability limits the extent of diffusion to an exponential times the number of discoverers.

To see this, consider biotechnology in 1973 and suppose that 6 people in 2 laboratories knew how to do genetic engineering (recombinant DNA). Suppose one knowledgeable person can transfer the knowledge to at most 1 person per year. Then the maximum number of potential practitioners of the art in year $t\left(t=0\right.$ in 1973) is $6 \cdot 2^{t}$. Even if this rapid rate of diffusion were possible, there would only be $6 \cdot 2^{10}=6,144$ potential practitioners of genetic engineering in 1983, each of whom would still be earning a very large shadow wage. Over time, the value of 
the knowledge declines as the number of practitioners increases until new apprentices earn only the normal human capital return to their investment in learning the knowledge.

Thus, there is a varying period of time during which the discovers and early learners derive supranormal returns from practicing their knowledge and also benefit from lower cost assistants due to the implicit tuition chain. This period of time can be long enough to significantly impact the formative period of a new industry, such as biotechnology or nanotechnology, or transformative periods such as have occurred in semiconductors. We have formulated a much more elaborate model involving multiyear learning in a lab with the number of learners in the lab and their probability and lag to leading their own lab, all as a function of the value of the knowledge, but the basic message of at most exponential growth from a small base remains intact. Zucker, Darby, and Torero (2002) illustrate both the geometric growth in scientists publishing their first paper reporting a genetic-sequence discovery and the continuing tacit nature of the knowledge. ${ }^{18}$

Discovering and other top scientists and engineers play a key role in metamorphic progress as we have seen so far for biotechnology and semiconductors, lasers as described by Sleeper (1998), and nanotechnology (based on our new research). We believe that natural excludability makes this role a frequent feature of metamorphic progress. Note that even where university professors follow the rules and promptly disclose inventions for patenting by the university under the Bayh-Dole Act, the value of those patents is impacted by the usual necessity to license the patent to a firm and on terms such that the discovering professors are willing to cooperate in the commercialization process. 


\section{Unsettled Welfare and Policy Issues}

Academic purists often express concerns about faculty involvement in commercialization of their discoveries. These concerns include: (a) lost scientific productivity of the scientists, (b) reduction in the amount of science which is contributed to the common pool by publishing, (c) deflection of the development of science toward more commercially relevant problems, (d) conflict of interest leading to scientists' distorting their findings, and (e) conflict of commitment to the university. Our research can shed light on some of these concerns, while others remain open issues. We do not consider more radical objections to scientific progress and productivity growth since we believe that these are well answered in more general debates.

\section{Lost Scientific Productivity of the Scientists}

One of the initial motivations of the biotechnology study which spawned our current larger growth, science, and technology project was to examine the cost in lost scientific productivity of commercial involvement of the very best academic bioscientists. Surprisingly, we found robust evidence that scientific productivity of these scientists increases during their commercial involvement (as compared to their own productivity before or after) on the standard measures of publications and citations to those publications (Zucker and Darby 1995, 1996). To give an extreme example, the most commercially involved star scientists (those ever affiliated with a firm and with patents) have 9 times as many citations as do star scientists who are never affiliated or linked to a firm and have no patents. About half of that difference reflects the fact that those who become involved are more energetic to begin with, and the rest the increase in publications per year and citations per publications during their years of firm involvement. 
In the half decade since we first published those findings, we have further tested them on an expanded U.S. data set using improved methodology and replicated them for Japan. Since publishing increases robustly for scientists working with firms, we were forced to reconsider our initial assumptions. First, the delays in publication required for patenting by firms are typically on the order of three months and universities also require delay while they prepare patent applications with possibly less efficiency. Further purely academic scientists also may prefer to delay publication for strategic reasons; one respondent put it this way: "When I was a pure academic, I didn't exactly throw away my lead by publishing rich discoveries until I put together three or four articles following them up." We may not only have over-estimated the increased returns to secrecy but also missed two factors which seem to swamp any higher value for secrecy.

The first countervailing factor is that commercial involvement gives the scientists much more resources to do their work. Not only are venture capitalists and investment bankers easier funding sources (per dollar) than the NIH or NSF, but it permits scientists the luxury of research assistants who are highly experienced and skilled long-term employees instead of first-year graduate students doing an assay or protocol for the first time.

The second countervailing factor is that the best scientists really love doing science! That is, doing science is a luxury good for which the income elasticity is greater than 1 . When their company goes public, they consume not only more Ferrari automobiles but more experiments. ${ }^{19}$

\section{Reduction in the Amount of Science Which Is Contributed to the Common Pool by Publishing}

These concerns in part refer to publishing activities by scientists who are commercially involved and those have been addressed above. There is, however, a broader concern that the commercialization of science will reduce the amount of publishing by scientists generally - thus 
reducing the positive externalities which enrich the entire enterprise. Put another way, extensive faculty involvement in the commercial world may import commercial norms of trade secrecy into the academy. Our evidence suggests that just the opposite is true and that the new biotech firms largely started with active faculty as principals - have exported academic values of publishing to the industries in which they are involved. The new biotech firms were a major organizational form/design innovation that forced the surviving incumbents to permit and reward journal publication in order to compete for the best and brightest scientists who are needed for the firm to survive and prosper. As the top research executive at one of the largest pharmaceutical firms put it: We see some danger of losing our competitive advantage by publishing, but a much greater danger if we do anything that deters the best scientists from coming here. Further, we need for our scientists to have great reputations in order to bring others like them to [the firm]. We are the beneficiaries of world-wide scientific research, and thus we also need to contribute to this pool of scientific knowledge, creating a public good.... Relative to new biotechnology firms, [we] may believe more strongly in the commonality of research tools because we have a wider array of methodologies and products. (Zucker and Darby 1997, pp. 438439.).

Table 3 is an extract of the top and "Other References" [i.e., non-patent references] section from Goeddel and Heyneker's (1982) U.S. Patent 4,342,832, assigned at issue to Genentech, Inc. The patent was applied for in July 1979 and cites related work by the inventors (Goeddel et al. published in the Proceedings of the National Academy of Sciences in the same year). Note the extensive citations to other work published in leading academic journals, indicating the continuity between basic science and new intellectual property in the science-driven industries. Indeed, much 
research done at firms is openly published either without a patent or shortly after one is applied for. In the most successful firms, world-class scientists are more likely to follow high-stakes, highreturns $R \& D$ strategies instead of more predictable incremental strategies, as indicated by the larger jump-size in their stock price when success or failure is revealed (Darby, Liu, and Zucker 2002).

The evidence is clear that the involvement of university faculty in commercialization of their discoveries has widened the norms of publication of research results into the very sciencedriven industries where there is the most to be learned from firm research. It is hard to credit that other university scientists are publishing less while those directly involved are publishing more; so we conclude that there has likely been an overall increase in the propensity to publish research results rather than the hypothesized decrease.

\section{Deflection of the Development of Science toward More Commercially Relevant Problems}

We believe that the trajectory of science is bent to a degree toward more commercially relevant problems. Just as provision of government research funding targeted to politically important issues would seem to have some impact on the trajectory of science, we would expect that the availability of commercial funding should also have an impact. However, it is very hard to develop a counterfactual trajectory for science, so our evidence is indirect: Zucker, Darby, and Torero (2002) find that bioscientists working in areas more directly relevant to human disease are more likely to become linked to firms, and, as noted above, scientists who are linked to firms are both generally more productive of articles and citations to those articles and are significantly more productive during their linkage than they were previously. Thus there must be some impact of commercial relevance on the course of science. However, since more science is being done in total 
and progress in one area depends in part on progress in other areas, we cannot conclude unambiguously that there is less progress in the less commercially applicable areas than there would have been in the absence of commercial involvement.

Even if there were less science in the less commercially applicable areas, it does not follow that this is a cost rather than a benefit. In the case of biotechnology, it means that more people are being spared from death and suffering from disease and from starvation due to high food costs. Possibly it is appropriate that scientists weigh these benefits directly and in terms of their financial implications in choosing which problems to work on. Even in economics, there are some distinguished practitioners who argue that their science would be healthier if empirical relevance played a greater role in allocation of rewards and hence choice of problems.

\section{Conflict of Interest Leading to Scientists' Distorting Their Findings}

From time to time cases of scientific fraud emerge, and the fear is that this frequency is inevitably increased where scientists can profit directly from selling products or shares of stock based on such claims. This is probably a very small risk for our star scientists who are likely at a robust corner solution due to reputations of immense value and realistic prospects for the Nobel and other major prizes. Where reputation value is lesser, one would expect that fraud increases with the returns. However, we do not normally argue against wealth creation on the grounds that it increases the incentives for theft and fraud.

\section{Conflict of Commitment to the University}

Finally, there is an argument that the opportunity to commercialize discoveries distracts faculty from the roles which they are paid for: to instruct, to do research, and to attend committee 
meetings. We can leave out any threat to research since that unambiguously increases in quantity and quality during commercial involvement, so the threat is concentrated in the areas of teaching and collegiality. Even for teaching, the issues are complicated by the extraordinarily high value of training received by apprentice researchers in the laboratories of scientists making valuable discoveries with natural excludability. If the possibility of working with such scientists increases the applications to the university in the relevant department(s) or school(s), can we truly say that their teaching output has decreased?

Moreover, in addressing the question of diversion from "commitment" to the university, we must face the issue that the roles or commitments of a professor are not standardized and are traditionally subject to individual negotiation as discussed by Stigler (1950) and Stinchcombe (1990). This immediately raises the issues of incentive packages and compensating differentials in wages of professors who - if they make a commercially valuable discovery - will tend to profit from the discovery as well as do more research and less teaching and collegiality. Normally, we would suppose that markets handle these contracting issues rather efficiently although not perfectly compared to a costless world (Darby and Karni 1973, Aghion and Tirole 1994). Possibly the complaints about conflict of commitments reflect more the feeling of some faculty in other departments that they work just as hard and should be equally rewarded by the market.

\section{Conclusions: A Draft Research Agenda}

The endogenous growth literature assumes that technology is a nonrivalrous recipe which is costly to discover but costless to replicate. We saw in Section IV above that for many industries undergoing metamorphic progress, technology instead possesses natural excludability, resides in 
particular individuals, and diffuses by learning-by-doing with. That is, breakthrough technologies are better thought of as rivalrous human capital, not a recipe on a disk capable of free copying. It follows that the focus of the endogenous growth literature should shift from the theory of the firm toward understanding the motivations of discovering scientists to report or bootleg discoveries, to found new firms or cooperate with existing firms in commercializing their discoveries, and most importantly to do the initial research which creates the opportunity for a commercial breakthrough. Key issues largely ignored in the current growth literature include compensating wage differentials, incentive pay, rents and quasi-rents, and moral hazard along the lines of Aghion and Tirole (1994). Jensen and Thursby (2001), Thursby and Thursby (2000), and Zucker, Darby, and Torero (2002) explicitly pursue those issues.

If the most important, breakthrough technologies are typically embodied in individual scientists and transferred or diffused by learning-by-doing-with, then the incentives to discover are considerably higher than conventionally analyzed even if the university or firm gets nominal ownership of the intellectual property rights in the discovery through a patent. The discoverers and patent-owner have an interesting bargaining problem since the patent is worthless unless the discoverers cooperate with the licensee(s), often firms in which the discoverers have founders' interests. On the other hand, the angel investors and venture capitalists financing discovers' firms want to be sure that the intellectual property is secure and tied down, so the discoverers must either negotiate a reasonable agreement with their employers (the patent owners) or take extraordinary steps to document that the discoveries were not made with, say, university resources. Hence, the plethora of firm laboratories very near campuses and the attraction of university-adjacent science parks to ensure that follow-up discoveries clearly belong to the firms and not the universities. 
Our approach also suggests that the analysis of spillovers (the S\&T literature's term for positive externalities) is basically flawed. The spillovers from the ivory tower that are widely used to explain geographically localized knowledge (i.e., increased research productivity for firms) in the neighborhood of great research universities do not hold up to rigorous empirical analysis. Increased research productivity is very large in firms with specific identifiable links to discovering university scientists and engineers and otherwise nil or insignificant. The more important positive externalities associated with commercialization of university discoveries have been neglected in the literature. These are the non-localized spillovers associated with increased publishing by the university scientists working with the firms and by the scientists and engineers employed by the firms. ${ }^{20}$

We know from a great deal of empirical research in the field of growth accounting that technological progress together with growth in the average level of human capital are the ultimate determinants of growth in output per capita. The endogenous growth literature has started the important work of understanding the determinants of technological progress in an aggregate model. The aggregate models to date are oriented toward explaining what we call perfective progress - based on incremental $R \& D$ performed by incumbent firms. We argue that metamorphic progress is an equal or greater source of technological progress and that most often - but not always - metamorphic progress involves discoveries made by scientists and engineers external to the existing industry and involves embodied knowledge which is protected by natural excludability and diffused by learning-by-doing-with. We believe that building on these ideas will strengthen both the science and technology and the endogenous growth literatures with the ultimate result that we understand what institutional arrangements are most conducive to growth in the standard of living. 


\section{REFERENCES}

Adams, James D., and Adam B. Jaffe, "Bounding the Effects of R\&D: An Investigation Using Matched Establishment-Firm Data." Rand Journal of Economics, Winter 1996, 27(4): 700-721.

Aghion, Philippe, and Jean Tirole, "The Management of Innovation," The Quarterly Journal of Economics, November 1994, 109(4): 1185-1209.

Aldrich, Howard, and Udo H. Staber, "Organizing Business Interests: Patterns of Trade Association Foundings, Transformations, and Death,” in Glenn R. Carroll, ed., Ecological Models of Organizations, Cambridge, MA: Ballinger Publishing Co., 1988.

Aldrich, Howard E., and Roger Waldinger, "Ethnicity and Entrepreneurship," Annual Review of Sociology, 1990; 16:111-135.

Arrow, Kenneth J., "Economic Welfare and the Allocation of Resources for Invention," in Richard R. Nelson, ed., The Rate and Direction of Inventive Activity: Economic and Social Factors, N.B.E.R. Special Conference Series vol. 13, Princeton, NJ: Princeton University Press, 1962. [Pp. 609-625]

Audretsch, David B., "New-Firm Survival and the Technological Regime," Review of Economics and Statistics, August 1991, 73(3): 441-450.

Audretsch, David B., and Maryann P Feldman, "R\&D Spillovers and the Geography of Innovation and Production," American Economic Review, June 1996, $\underline{86}$ (3): 630-640.

Bania, Neil, Randall Eberts, and Michael Fogarty, "Universities and the Startup of New Companies: Can We Generalize from Route 128 and Silicon Valley?" Review of Economics and Statistics, November 1993, 75(4): 761-766. 
Barnett, William P., and Terry L. Amburgey, "Do Larger Organizations Generate Stronger Competition?" in Jitendra V. Singh, ed., Organizational Evolution: New Directions, Newbury Park, CA: Sage Publications, 1990.

Baum, Joel A. C., "Organizational Ecology," in Stewart R. Clegg, Cynthia Hardy, and Walter R. Nord, eds., Handbook of Organization Studies. London, U.K.: Sage Publications, 1996.

Baum, Joel A. C., and Walter W. Powell, "Cultivating an Institutional Ecology of Organizations: Comment on Hannan, Carroll, Dundon, and Torres," American Sociological Review, August 1995, $\underline{60}(4):$ 529-538.

Becker, Gary S., Human Capital: A Theoretical and Empirical Analysis, with Special Reference to Education, Chicago, IL: University of Chicago Press, 1964.

Bernardo, Antonio E., and Bhagwan Chowdhry, "Resources, Real Options, and Corporate Strategy," Journal of Financial Economics, in press 2002.

Brittain, Jack W., and John H. Freeman, "Entrepreneurship in the Semiconductor Industry," paper presented at the $46^{\text {th }}$ Annual Meeting of the Academy of Management, New Orleans, 1986.

Carroll, Glenn R., and Michael T. Hannan. "Density Dependence in the Evolution of Populations of Newspaper Organizations," American Sociological Review, Aug. 1989, 54(4): 524-541.

Caves, Richard E. "Industrial Organization and New Findings on the Turnover and Mobility of Firms," Journal of Economic Literature, December 1998, 36(4): 1947-1982.

Cohen, Stanley, and Herbert Boyer, "Process for producing biologically functional molecular chimeras," United States Patent number 4,237,224, granted December 2, 1980. 
Cohen, Stanley, A. Chang, Herbert Boyer, and R. Helling, "Construction of Biologically Functional Bacterial Plasmids in vitro," Proceedings of the National Academy of Sciences, November 1973, $\underline{70}(11): 3240-3244$.

Darby, Michael R., Labor Force, Employment, and Productivity in Historical Perspective, Monograph and Research Series, No. 37, Los Angeles, CA: U.C.L.A. Institute of Industrial Relations, 1984. (1984a)

Darby, Michael R., "The U.S. Productivity Slowdown: A Case of Statistical Myopia," American Economic Review, June 1984, 74: 301-322. (1984b)

Darby, Michael R., and Edi Karni, "Free Competition and the Optimal Amount of Fraud," Journal of Law and Economics, April 1973, 16: 67-88.

Darby, Michael R., Qiao Liu, and Lynne G. Zucker, "High Stakes in High Technology: Hightech Market Values as Options," UCLA working paper April 2002 [revised version of National Bureau of Economic Research Working Paper No. 7201, June 1999.]

Darby, Michael R., and Lynne G. Zucker, "Change or Die: The Adoption of Biotechnology in the Japanese and U.S. Pharmaceutical Industries," Comparative Studies of Technological Evolution, 2001, 7: 85-125.

Davis, Steven J., and John Haltiwanger, "Gross Job Creation, Gross Job Destruction, and Employment Reallocation," Quarterly Journal of Economics, August 1992, 107(3): 819863.

Dorfman, Nancy S., "Route 128: The Development of a Regional High Technology Economy," in David Lampe, ed., The Massachusetts Miracle: High Technology and Economic Revitalization, Cambridge, MA: MIT Press, 1988. 
Ericson, Richard, and Ariel Pakes, "Markov-Perfect Industry Dynamics: A Framework for Empirical Work," Review of Economic Studies, January 1995, 62(1): 53-82.

Federal Reserve Bank of Kansas City, Economic Policy for the Information Economy, A Symposium Sponsored by the Federal Reserve Bank of Kansas City, Kansas City, MO: Federal Reserve Bank of Kansas City, 2001.

Freeman, John, Glenn R. Carroll, and Michael T. Hannan, "The Liability of Newness: Age Dependence in Organizational Death Rates," American Sociological Review, October 1983, 48(5): 692-710.

Goeddel, David V., Dennis G. Kleid, Francisco Bolivar, Herbert L. Heyneker, Daniel G. Yansura, Roberto Crea, Tadaaki Hirose, Adam Kraszewski, Keiichi Itakura, and Arthur D. Riggs, "Expression in Escherichia coli of Chemically Synthesized Genes for Human Insulin," Proceedings of the National Academy of Sciences, January 1979, 76(1): 106110.

Goeddel, David V., and Herbert L. Heyneker, "Method of constructing a replicable cloning vehicle having quasi-synthetic genes," United States Patent number 4,342,832, granted August 3, 1982.

Greenspan, Alan, "Technology and the economy," Remarks before the Economic Club of New York, New York, NY, January 13, 2000. [http://www.federalreserve.gov/ boarddocs/speeches/2000/200001132.htm] (2000a)

Greenspan, Alan, "Technological innovation and the economy," Remarks before the White House Conference on the New Economy, Washington, D.C., April 5, 2000. [http://www.federalreserve.gov/boarddocs/speeches/2000/20000405.htm] (2000b) 
Greenspan, Alan, "Economic developments," Remarks before the Economic Club of New York, New York, NY, May 24, 2001. [http://www.federalreserve.gov/boarddocs/speeches/ 2001/200105242/default.htm] (2001)

Griliches, Zvi, "Hybrid Corn: An Exploration in the Economics of Technological Change," Econometrica, October 1957, 25(4): 501-522.

Griliches, Zvi, "Hybrid Corn and the Economics of Innovation," Science, July 29, 1960, 132(no. 3422): 275-280.

Griliches, Zvi, and Jacob Schmookler, "Inventing and Maximizing," American Economic

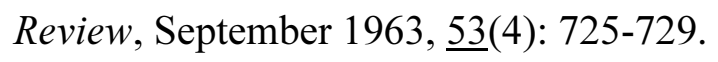

Haltiwanger, John C., "Measuring and Analyzing Aggregate Fluctuations: The Importance of Building From Microeconomic Evidence," Federal Reserve Bank of St. Louis Review,

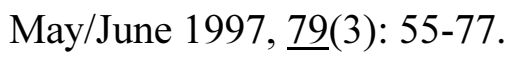

Harberger, Arnold C., "A Vision of the Growth Process," American Economic Review, March $1998, \underline{88(1): 1-32 .}$

Head, Keith, John Ries, and Deborah Swenson, "Agglomeration Benefits and Location Choice: Evidence from Japanese Manufacturing Investments in the United States," Journal of International Economics, May 1995, $\underline{38(3-4): ~ 223-247 . ~}$

Henderson, Rebecca, "Underinvestment and Incompetence as Responses to Radical Innovation: Evidence from the Photolithographic Alignment Industry," RAND Journal of Economics, Summer 1993, 24 (2): 248-270.

Henderson, Rebecca, Adam B. Jaffe, and Manuel Trajtenberg, "Universities as a Source of Commercial Technology: A Detailed Analysis of University Patenting 1965-1988," Review of Economics and Statistics, February 1998, 0⑴: 119-127. 
Jaffe, Adam B., "Technological Opportunity and Spillovers of R \& D; Evidence from Firms' Patents, Profits, and Market Value," The American Economic Review, December 1986, 76(5): 984-1001.

Jaffe, Adam B., "Characterizing the 'Technological Position' of Firms, with Application to Quantifying Technological Opportunity and Research Spillovers," Research Policy, $1989, \underline{18}(1): 87-97$.

Jaffe, Adam B., Manuel Trajtenberg, and Rebecca Henderson, "Geographic Localization of Knowledge Spillovers as Evidenced by Patent Citations," Quarterly Journal of Economics, August 1993, 63(3): 577-598.

Japan Times, "Professor Guilty in Drugs Bribes Case," Japan Times International Edition, April $18,1999$.

Jensen, Richard, and Marie Thursby, "Proofs and Prototypes for Sale: The Tale of University Licensing," American Economic Review, March 2001, 91(1): 240-259.

Jones, Bryan D., and Arnold Vedlitz, "Higher Education Policies and Economic Growth in the American States," Economic Development Quarterly, February 1988, 2 (1): 78-87.

Jovanovic, Boyan, "Selection and the Evolution of Industry," Econometrica, May 1982, 50(3): 649-670.

Jovanovic, Boyan, and Glenn MacDonald, "The Life-Cycle of a Competitive Industry," Journal of Political Economy, April 1994, 102(2): 322-347.

Klepper, Steven, "Entry, Exit, Growth, and Innovation over the Product Life Cycle," American Economic Review, June 1996, 86(3): 562-583. 
Klepper, Steven, and John H. Miller, "Entry, Exit, and Shakeouts in the United States in New Manufactured Products," International Journal of Industrial Organization, 1995, 13(4): $567-91$.

Knight, Frank H., "Diminishing Returns from Investment," Journal of Political Economy, March 1944, $\underline{52}(1): 26-47$.

Lamoreaux, Naomi R., and Kenneth L. Sokoloff, "Inventive Activity and the Market for Technology in the United States, 1840-1920," paper presented at the Second Annual Roundtable for Engineering Entrepreneurship Research (REER), DuPree College of Management at Georgia Tech, Atlanta, Georgia, March 21-23, 2002. 2002.

Landefeld, J. Steven, and Barbara M. Fraumeni, "Measuring the New Economy," Survey of Current Business, March 2001, 81(3): 23-40.

Lerner, Abba P., "On the Marginal Product of Capital and the Marginal Efficiency of Investment," Journal of Political Economy, February 1953, 61(1): 1-14.

Lippman, Steven A., and Richard P. Rumelt, "Uncertain Imitability: An Analysis of Interfirm Differences in Efficiency under Competition," Bell Journal of Economics, Autumn 1982, 13(2): 418-438.

Mansfield, Edwin, "Technical Change and the Rate of Imitation," Econometrica, October 1961, 29(4): 741-766.

Mansfield, Edwin, "Entry, Gibrat's Law, Innovation, and the Growth of Firms," American Economic Review, December 1962, 52(5): 1023-1051.

Mansfield, Edwin, "Academic Research Underlying Industrial Innovations: Sources, Characteristics, and Financing," Review of Economics and Statistics, February 1995, 77(1): 55-65. 
Marrett, Cora Bagley. "Influences on the Rise of New Organizations: The Formation of Women"s Medical Societies." Administrative Science Quarterly, March 1980, 25(1): 185-199.

McCarthy, John D., Mark Wolfson, David P. Baker, and Elaine Mosakowski, "The Founding of Social Movement Organizations," in Glenn R. Carroll, ed., Ecological Models of Organizations, Cambridge, MA: Ballinger Publishing Co., 1988.

McKelvey, Bill, Organizational Systematics: Taxonomy, Evolution, Classification, Berkeley, CA: University of California Press, 1982.

McKelvey, Bill, and Howard Aldrich, "Populations, Natural Selection, and Applied Organizational Science," Administrative Science Quarterly, March 1983, 28(1): 101-128.

Miner, Anne S., Terry L. Amburgey, and Timothy M. Stearns. "Interorganizational Linkages and Population Dynamics: Buffering and Transformational Shields," Administrative Science Quarterly, December 1990, 35(4): 689-713.

Nelson, Richard R., "The Economics of Invention: A Survey of the Literature," Journal of Business, April 1959, 32(2): 101-127.

Pakes, Ariel, and Richard Ericson, "Empirical Implications of Alternative Models of Firm Dynamics," Journal of Economic Theory, March 1998, 79(1): 1-46.

Romanelli, Elaine, "The Evolution of New Organizational Forms," Annual Review of Sociology, 1991, 17: 79-103.

Romer, Paul M., "Endogenous Technological Change," Journal of Political Economy, 1990, $\underline{9}$ (5, Part 2--Supplement): S71-S102. 
Rudebusch, Glenn D., "How Fast Can the New Economy Grow?" FRBSF Economic Letter, Number 2000-05; February 25，2000. [http://www.frbsf.org/econrsrch/wklyltr/2000/ el2000-05.html]

Schumpeter, Joseph A., The Theory of Economic Development, Redvers Opie, trans., Harvard Economic Studies vol. 46, Cambridge, MA: Harvard University Press, 1934.

Singh, Jitendra V., and Charles J. Lumsden, "Theory and Research in Organizational Ecology," Annual Review of Sociology, 1990, 16: 161-195.

Sleeper, Sally D., The Role of Firm Capabilities in the Evolution of the Laser Industry: The Making of a High-Tech Market, unpublished Ph.D. dissertation, Carnegie Mellon University, Pittsburgh PA, 1998.

Smilor, Raymond W., George Kozmetsky, and David V. Gibson, Creating the Technopolis: Linking Technology, Commercialization, and Economic Development, Cambridge, MA: Ballinger Publishing Co., 1988.

Stigler, George J., Employment and Compensation in Education, National Bureau of Economic Research Occasional Paper 33, New York, NY: National Bureau of Economic Research, 1950.

Stigler, George J., "The Economics of Information," Journal of Political Economy, June 1961, 69(3): 213-225.

Stinchcombe, Arthur L., "Organizations and Social Structure," in James G. March, ed., Handbook of Organizations, Chicago: Rand McNally, 1965.

Stinchcombe, Arthur L., "University Administration of Research Space and Teaching Loads: Mangers Who Do Not Know What Their Workers Are Doing," in A.L. Stinchcombe, Information and Organizations, Berkeley, CA: University of California Press, 1990. 
Thursby, Jerry G., and Marie Thursby, "Who Is Selling the Ivory Tower? Sources of Growth in University Licensing," Management Science, January 2002, 48(1): 90-104.

Torero, Maximo, "Analyzing the Spillover Mechanism on the Semiconductor Industry in the Silicon Valley and Route 128," chapter 1 in Torero, Maximo, Essays on Diffusion of Technical Change, unpublished Ph.D. dissertation, UCLA Economics Department, 1998.

Torero, Máximo, Michael R. Darby, and Lynne G. Zucker, "The Importance of Intellectual Human Capital in the Birth of the Semiconductor Industry," UCLA Working Paper, January 2001.

Tushman, Michael L., and Philip Anderson, "Technological Discontinuities and Organizational Environments," Administrative Science Quarterly, March 1986, 31(1): 439-465.

Wedervang, Frőystein, Development of a Population of Industrial Firms: The Structure of Manufacturing Industries in Norway, 1930-1948, Oslo, Norway: Universitetsforlaget, 1965.

Zucker, Lynne G., "Combining Institutional Theory and Population Ecology: No Legitimacy, No History," American Sociological Review, Aug. 1989, 54(4): 542-545.

Zucker, Lynne G., and Michael R. Darby, "Virtuous Circles of Productivity: Star Bioscientists and the Institutional Transformation of Industry," National Bureau of Economic Research Working Paper No. 5342, November 1995.

Zucker, Lynne G., and Michael R. Darby, "Star Scientists and Institutional Transformation: Patterns of Invention and Innovation in the Formation of the Biotechnology Industry," Proceedings of the National Academy of Sciences, November 12, 1996, 93(23): 12,70912,716 . 
Zucker, Lynne G., and Michael R. Darby, "Present at the Biotechnological Revolution: Transformation of Technical Identity for a Large Incumbent Pharmaceutical Firm," Research Policy, December 1997, 26(4\&5): 429-446.

Zucker, Lynne G., and Michael R. Darby, "Capturing Technological Opportunity Via Japan's Star Scientists: Evidence from Japanese Firms' Biotech Patents and Products," Journal of Technology Transfer, January 2001, 266(1/2): 37-58.

Zucker, Lynne G., Michael R. Darby, and Jeff Armstrong, "Geographically Localized

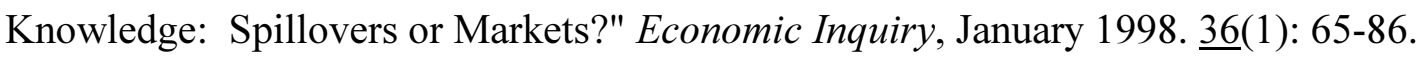

Zucker, Lynne G., Michael R. Darby, and Jeff Armstrong, "Commercializing Knowledge: University Science, Venture Capital, and Firm Performance in Biotechnology," Management Science, January 2002, 스(1): 138-153.

Zucker, Lynne G., Michael R. Darby, and Marilynn B. Brewer, "Intellectual Human Capital and the Birth of U.S. Biotechnology Enterprises," American Economic Review, March 1998, 88(1): 290-306.

Zucker, Lynne G., Michael R. Darby, and Yusheng Peng, "Fundamentals or Population Dynamics and the Geographic Distribution of U.S. Biotechnology Enterprises, 19761989," National Bureau of Economic Research Working Paper No. 6414, February 1998.

Zucker, Lynne G., Michael R. Darby, and Máximo Torero, "Labor Mobility from Academe to Commerce," Journal of Labor Economics, in press 2002. 


\section{FOOTNOTE}

${ }^{1}$ Abba Lerner (1953) also propagated the Crusonia plant.

${ }^{2}$ See, for example, the papers collected in Federal Reserve Bank of Kansas City (2001).

${ }^{3}$ If it were the point of the paper, we would do a full analysis of productivity growth taking account of changes in capital, labor-quality adjustments for the hours worked, and pro-cyclical movements in productivity (see Darby 1984a-b). Before undertaking such an effort, we would want to see evidence of an interesting anomaly in cruder measures of productivity growth. Central bankers saying that the economy works differently from before so that they can ignore the usual signs of monetary over-stimulus hardly qualify as an anomaly.

${ }^{4}$ Rudebusch clearly walked a tight line between professional and institutional loyalty: "As noted above, there is, of course, always a large amount of uncertainty about estimates of the growth rate of potential output. Indeed, based on a strict statistical interpretation of Figure 1, there is a one in five chance that there has been no change in the growth of potential output in the 1990s."

${ }^{5}$ Growth in overall industry size can be attributed to movement down an elastic demand curve as more efficient lower cost producers replace higher cost producers. The question is why does it take so long for the low cost producers to emerge and drive out the others.

${ }^{6}$ Zucker (1989), Baum and Powell (1995), as well as the review articles by Baum (1996) and by Singh and Lumsden (1990), raise significant questions about the directions of theory and research in organizational ecology, while at the same time stressing the value of particular empirical studies done under the ecology banner.

${ }^{7}$ Compare infant mortality in Wedervang (1965) to liability of smallness, ruling out age effects, in Freeman, Carroll, and Hannan (1983).

${ }^{8} \mathrm{New}$ industries may eliminate or greatly reduce the size of other industries previously satisfying 
the fundamental function - e.g., the advent of the automobile industry all but eliminated both the buggy and buggy whip industries. In principle, we could view the present automobile and vestigial buggy industries as a transformed personal land transportation industry, but it is not apparent what would be gained from such semantic niceties.

${ }^{9}$ The range and impact of incumbent-enhancing metamorphic change is suggested by Harberger's ongoing work on major cost reductions in existing industries.

${ }^{10}$ This process may interact with waves of optimism and pessimism about the future of an emerging industry. For example, despite a promising and ultimately successful pipeline of drug discoveries, Cetus faced a cash shortage during a phase of biotech-pessimism and merged into Chiron.

${ }^{11}$ Zucker, Darby, and Armstrong (2002).

${ }^{12}$ Note that we maintained the decile sorting by level of 1989 employment in Figure 3. If we had instead sorted by employment change along the lines of Harberger (1998), the top and second deciles so-defined would account for 75.8 and 17.4 percent of the net employment change with only $6.7 \%$ left for the other firms. The bottom $80 \%$ (169 firms) on this basis includes 63 firms with negative change, 10 with no change, and 96 firms with positive employment change.

${ }^{13}$ See especially, Nancy S. Dorfman (1988), Bryan D. Jones and Arnold Vedlitz (1988), Raymond W. Smilor, George Kozmetsky, and David V. Gibson (1988), Neil Bania, Randall Eberts, and Michael Fogarty (1993). There are, of course, other important sources of geographic agglomeration (see, for example, Keith Head, John Ries, and Deborah Swenson 1994).

${ }^{14}$ Publications involving scientists at two firms are extremely rare. Further, the scientists practice serial monogamy: usually writing with only one firm during his or her career and, in the alternative, writing with only one firm at a time. 
${ }^{15}$ We introduce major methodological innovations in Zucker, Darby, and Armstrong (2002), exploiting a substantially broadened database, so that simple comparisons are not possible although the results are very supportive of the importance of academic-firm linked articles.

${ }^{16}$ In Japan, explicit principal status in a firm is forbidden to professors at the national universities. However, continuing unreported cash payments on the order of the scientist's salary are common (and rarely prosecuted, but see Japan Times 1999 for a counter-example) as are lucrative corporate directorships promised when the professor "descends from heaven" at age 55 or 60 (i.e., post-retirement).

${ }^{17}$ Sometimes when an important result is difficult to reproduce in another location, the entire laboratory is reproduced including the placement of equipment down to the coffee urn. If the result can then be obtained, detective work ensues to figure out what features are crucial. In a similar vein, during our fieldwork we heard one distinguished scientist grumble that another "had stolen my best cloner." This is not a remark applicable to something easy to learn from material written on a floppy disk!

${ }^{18}$ Tacitness is indicated by the fact that the bulk of new authors reporting genetic-sequence discoveries for the first time were writing as co-authors with previously published discovers and this continued to the end of the data set (1994), as reported in Zucker, Darby, and Torero (2002). ${ }^{19}$ Milton Friedman reminds us that economists are not immune to this science as [tax-exempt or conspicuous?] consumption phenomenon: Irving Fisher amassed a fortune inventing a visible file system and founding one of the constituents of Remington-Rand. He used it to hire a sizable staff of assistants to compute $\left(X^{\prime} X\right)^{-1} X^{\prime} y$ in the days before electric calculators. The ability to estimate multiple regressions was a powerful professional advantage in the 1920s.

${ }^{20}$ We are indebted to Milton Friedman for this point. 
Table 1

Concentration of Employment in New Biotech Firms, 1989

$\begin{array}{lcc} & \begin{array}{c}\text { Number } \\ \text { of Firms }\end{array} & \begin{array}{c}\text { Employment } \\ \text { in } 1989\end{array} \\ \text { Top Decile } & 21 & 53.8 \% \\ \text { Next Decile } & 21 & 15.0 \% \\ \text { Bottom } 80 \% & 169 & 31.2 \% \\ \text { Totals } & 211 & 100.0 \%\end{array}$

Source: Calculations of the authors for the biotech-using firms which disclosed employment for 1989 and 1994 and were formed after 1975 in the Zucker, Darby, and Armstrong (2002) database. 
Table 2

Relation of Employment in New Biotech Firms to Links to High Science

As Represented by Articles Co-Authored with Scientists in Top 112 Research Universities

$\begin{array}{lcccc}\begin{array}{l}\text { Number } \\ \text { of Firms }\end{array} & \begin{array}{c}\text { Employment } \\ \text { in } 1989\end{array} & \begin{array}{c}\text { Employment } \\ \text { Change 1989-94 }\end{array} & \begin{array}{c}\text { Core Links to } \\ \text { Top Universities }\end{array} & \begin{array}{c}\text { Other Links to } \\ \text { Top Universities }\end{array}\end{array}$

By 1989 Employment:

\begin{tabular}{lccccc} 
Top Decile & 21 & $53.8 \%$ & $53.2 \%$ & $76.4 \%$ & $79.4 \%$ \\
Next Decile & 21 & $15.0 \%$ & $9.4 \%$ & $6.2 \%$ & $4.0 \%$ \\
Bottom 80\% & 169 & $31.2 \%$ & $37.4 \%$ & $17.4 \%$ & $16.6 \%$ \\
\cline { 2 - 6 } Totals & 211 & $100.0 \%$ & $100.0 \%$ & $100.0 \%$ & $100.0 \%$ \\
& & & & & \\
Core Links & & & & & \\
Top Decile & 21 & $48.7 \%$ & $53.4 \%$ & $94.0 \%$ & $7.5 \%$ \\
Next Decile & 21 & $7.1 \%$ & $4.6 \%$ & $5.1 \%$ & $10.7 \%$ \\
Bottom 80\% & 169 & $44.2 \%$ & $42.0 \%$ & $0.9 \%$ & $100.0 \%$ \\
Totals & 211 & $100.0 \%$ & $100.0 \%$ & $100.0 \%$ &
\end{tabular}

Core links are a count of articles published through 1989 in journals directly related to biotechnology which are indexed by the Institute of Scientific Information and with one or more authors affiliated with the firm and one or more authors affiliated with any of the top 112 U.S. research universities in terms of receipt of federal research funding.

Other links are a count of articles published through 1989 in journals not directly related to biotechnology which are indexed by the Institute of Scientific Information and with one or more authors affiliated with the firm and one or more authors affiliated with any of the top 112 U.S. research universities in terms of receipt of federal research funding.

Source: Calculations of the authors for the biotech-using firms which disclosed employment for 1989 and 1994 and were formed after 1975 in the Zucker, Darby, and Armstrong (2002) database. 
Table 3

Extract from U.S. Patent 4,342,832, Assigned to Genentech, Inc.

Illustrating Close Ties to Academic Science

United States Patent

$4,342,832$

Goeddel, et al.

August 3, 1982

Method of constructing a replicable cloning vehicle having quasi-synthetic genes

\section{Abstract}

Described are methods and means for the construction and microbial expression of quasi-synthetic genes arising from the combination of organic synthesis and enzymatic reverse transcription from messenger RNA sequences incomplete from the standpoint of the desired protein product. Preferred products of expression lack bio-inactivating leader sequences common in eukaryotic expression products but problematic with regard to microbial cleavage to yield bioactive material. Illustrative is a preferred embodiment in which a gene coding for human growth hormone (useful in, e.g., treatment of hypopituitary dwarfism) is constructed and expressed.

Inventors: $\quad$ Goeddel; David V. (Burlingame, CA); Heyneker; Herbert L. (Burlingame, CA)

Assignee: $\quad$ Genentech, Inc. (South San Francisco, CA)

Appl. No: $\quad 055126$

Filed: $\quad$ July 5,1979

\section{Other References}

Technology Review, pp. 12 and 13, Dec. 1976.

Martial et al., Science, vol. 205, Aug. 10, 1979.

Shine et al., Nature, vol. 285, Jun. 12, 1980, pp. 456-461.

The Economist, pp. 87 and 88, Jul. 14, 1979.

Time, Jul. 30, 1970, p. 70.

Newmark, Nature, vol. 280, pp. 637 and 638, Aug. 23, 1979.

Villa-Komaroff et al., Proc. Natl. Acad. Sci., vol. 75, pp. 3727-3731, Aug. 1978.

Seeburg et al., Nature, vol. 276, pp. 795-798, Dec. 1978.

Itakura et al., Science, vol. 198, pp. 1056-1063, Dec. 1977.

Crea et al., Proc. Natl. Acad. Sci., vol. 75, pp. 5765-5769, Dec. 1978.

Klenow et al., Proc. Natl. Acad. Sci., vol. 65, pp. 168-175, Jan. 1970.

Sutcliffe, Cold Spring Harbor Symposium 43, pp. 70-90 (1978).

Curtis et al., Molecular Cloning of Recombinant DNA, by Scott et al., pp. 99-111 (1977).

Ullrich et al., Science, vol. 196, pp. 1313-1319, Jun. 1977.

Bolivar et al., Gene 2, pp. 95-113 (1977).

Goedel et al., Proc. Natl. Acad. Sci., vol. 76, pp. 106-110, Jan. 1979.

Chang et al., Nature, vol. 275, pp. 617-624, Oct. 1978.

Maxam et al., Proc. Nat. Acad. Sci., vol. 74, pp. 560-564 (Feb. 1977).

Kornberg, DNA Synthesis, pp. 87 and 88, pub. by W. H. Freeman \& Co., 1974.

Razin et al., Proc. Natl. Acad., vol. 75, pp. 4268-4270, Sep. 1978.

Wickens et al., The Journal of Biological Chemistry, vol. 253, No. 7, pp. 2483-2495 (1978). 


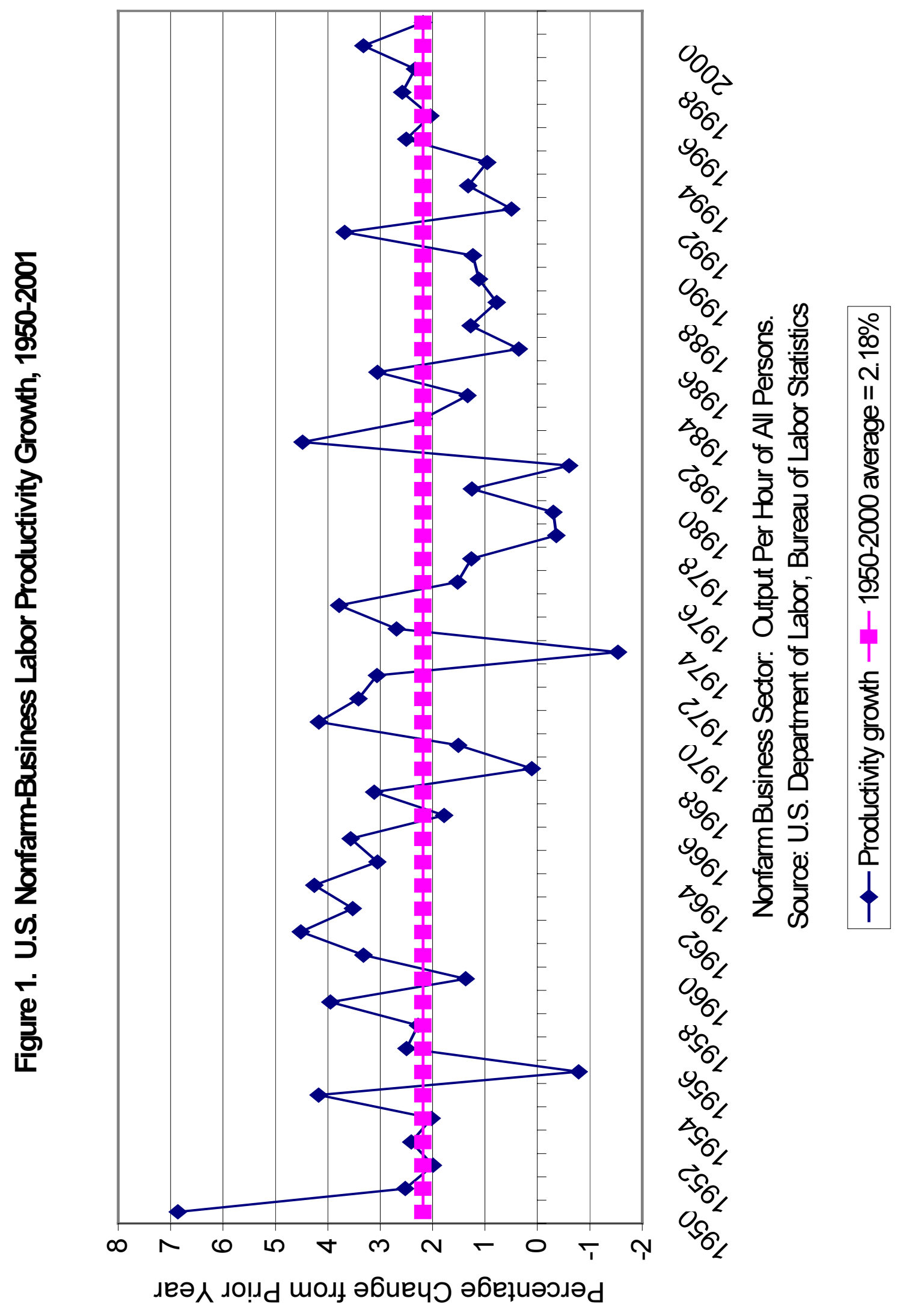




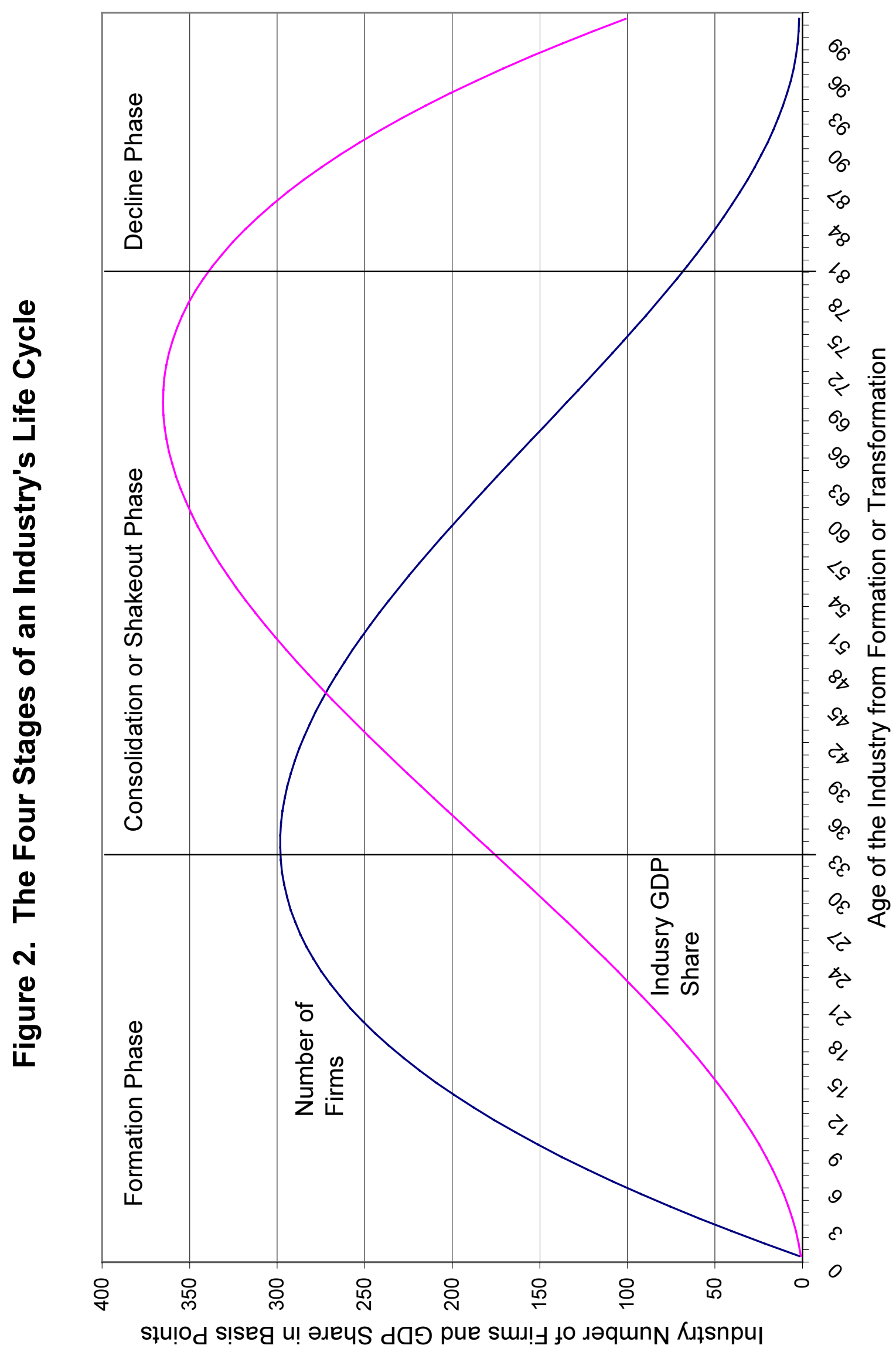


Figure 3. Concentration of U.S. New Biotechnology Firms' 1989 Employment and Employment Change 1989-1994

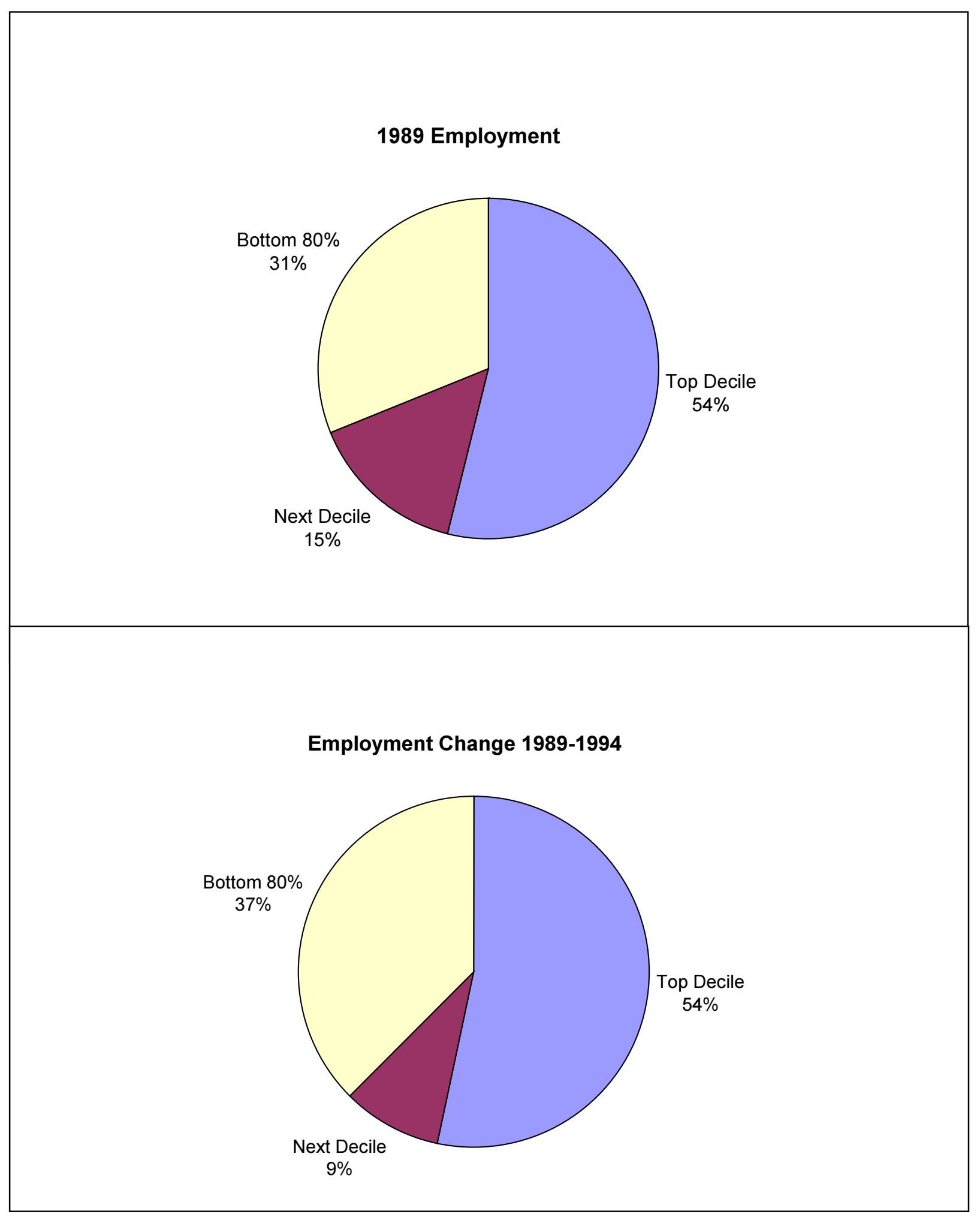


Figure 4. Concentration of New Biotechnology Firms' Links to Top Research Universities for 1989 Employment Deciles

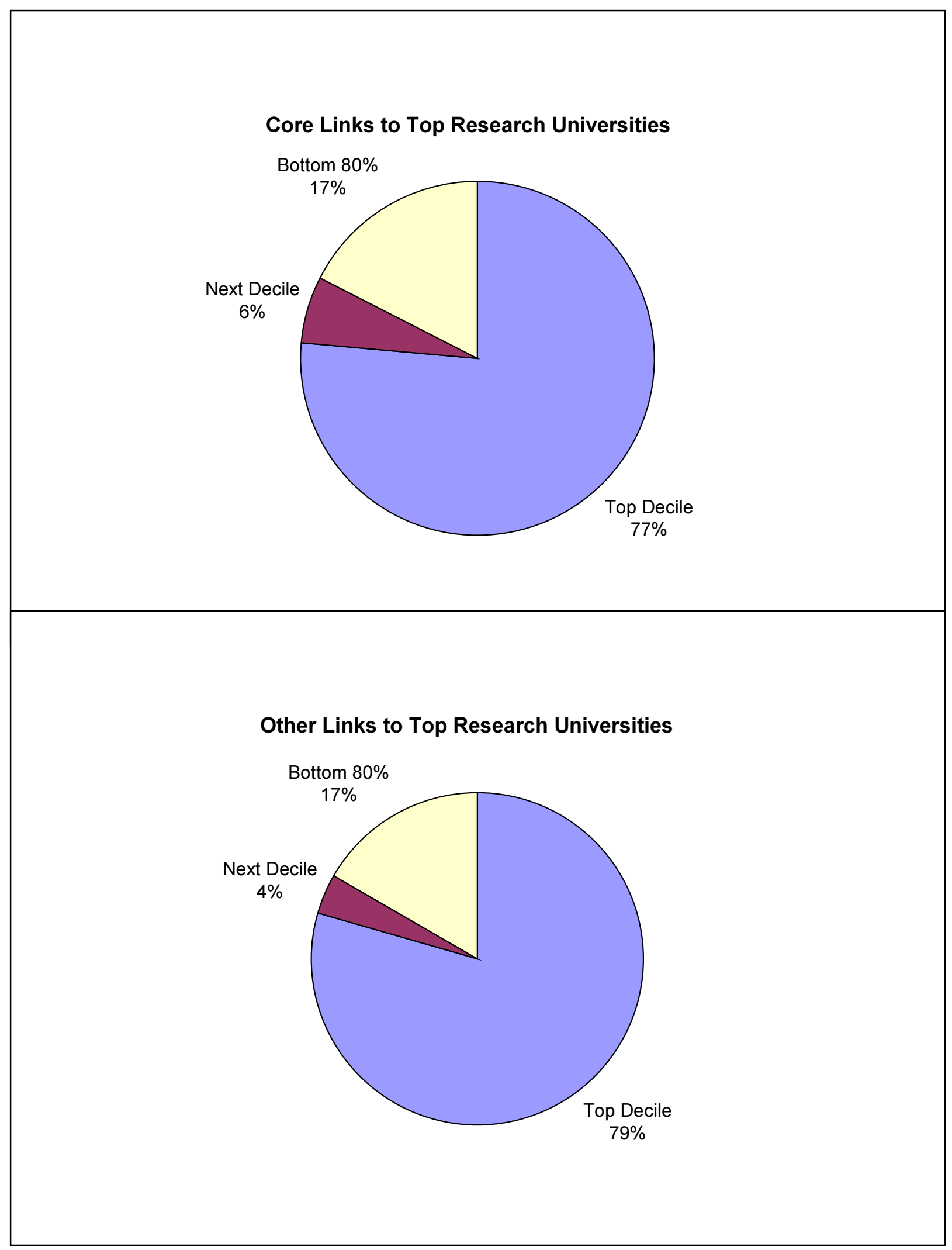



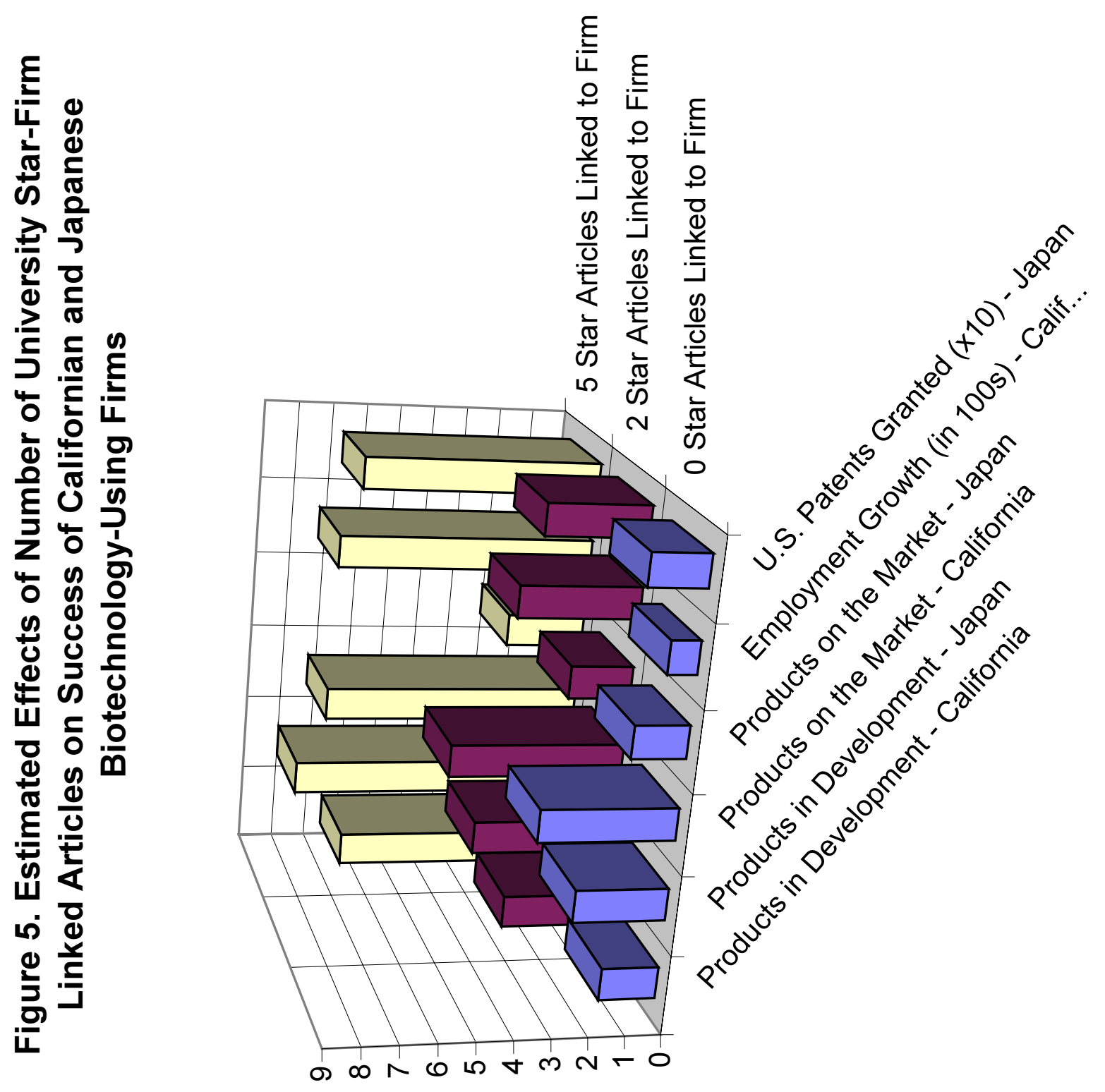